\title{
The Impact of Financial Disintermediation on the Credit Business of Chinese Commercial Banks
}

\author{
Ruixiong Qi ${ }^{1}$, Jia Wang1, Ronghua Chang1, Yuanyuan Shen ${ }^{2}$ \\ ${ }^{1}$ Business School, Shanxi Datong University, Datong, China \\ ${ }^{2}$ Datong Branch, China Construction Bank, Datong, China \\ Email: qrx_dtdx@163.com
}

How to cite this paper: Qi, R. X., Wang, J., Chang, R. H., \& Shen, Y. Y. (2021). The Impact of Financial Disintermediation on the Credit Business of Chinese Commercial Banks. Open Journal of Social Sciences, 9, 288-298.

https://doi.org/10.4236/jss.2021.912019

Received: November 23, 2021

Accepted: December 14, 2021

Published: December 17, 2021

Copyright $\odot 2021$ by author(s) and Scientific Research Publishing Inc. This work is licensed under the Creative Commons Attribution International License (CC BY 4.0).

http://creativecommons.org/licenses/by/4.0/

\begin{abstract}
China's capital market has been increasingly improved and financial reform has been deepened in recent years. With the rapid growth of Internet finance, funds have gradually separated from traditional commercial banks or other intermediaries and quickly turned to the financial market with low financing cost. The trend of financial disintermediation has been increasing. Affected by the trend of "financial disintermediation", the supply of money market has slowed down significantly. Large-scale capital bypassed financial intermediaries such as commercial banks, flowed into trust financing, private lending, and entered the NEEQ market, bonds, stocks or other financing channels. Based on the actual situation of commercial banks, this article analyzes the impact of credit business under the trend of financial disintermediation, and proposes countermeasures for Chinese commercial banks in terms of optimizing business structure, accelerating strategic transformation and reforming traditional service models, with a view to proactively responding to the challenge of financial disintermediation and accelerate the realization of strategic transformation, structural adjustment and financial reform.
\end{abstract}

\section{Keywords}

Financial Disintermediation, Commercial Banks, Credit Business

\section{Introduction}

Financial disintermediation arose in the United States in 1960s. The Federal Reserve issued Regulation Q in order to set the upper limit of interest rate of U.S. savings deposits and commercial banks' time deposits in 1966. However, the upper limit of US deposit interest rates stipulated by Regulation Q is lower than 
the actual interest rate in financial market. Therefore, capital flows to the capital market with higher returns and lower financing costs, gradually leaving the banking system. Funds crossed commercial banks and other traditional financial institutions quickly enter the capital market, prompting the rapid growth of the direct financing market. This economic phenomenon is called financial disintermediation. The phenomenon of financial disintermediation becomes inevitable when the financial market has developed to a mature stage and this phenomenon has appeared one after another.

China's financial market has developed rapidly, financial reforms have continued to deepen, and financial disintermediation has also occurred in the 1990s. Indirect financing, usually dominated by Chinese commercial banks, has weakened its position in the financial system, and residents' investment channels and corporate financing channels have shown a multi-selective and diversified trend. Earning deposit-loan spreads is the traditional profit model of Chinese commercial banks. However, the current direct financing market is becoming more and more perfect. Residents withdraw idle funds from banks and turn to high-yield capital markets. Companies can obtain funds with flexible and diverse methods and not just rely solely on commercial bank loans. Direct financing by issuing bonds or stocks in the capital market is effective. Therefore, the financial intermediary status of commercial banks has been challenged and deeply trapped in two-way disintermediation. The development of traditional models is unsustainable.

The year of 2013 is considered to be the "first year of the Internet", and the rapid rise of Internet finance has exerted tremendous influence and impact on Chinese commercial banks. The state's support for entrepreneurship policies has created a good financing environment for SMEs. The SMEs' financing needs have emerged. The financial service needs of SMEs cannot match the credit business of traditional commercial banks, and commercial banks fallen into a business "bottleneck". The credit business of traditional commercial banks received a huge impact in the "blowout" development of Internet consumer finance. The total amount of commercial bank loans gradually declined, and small business customers have been losing. The Internet online credit platform represented by $\mathrm{P} 2 \mathrm{P}$ divides the share of traditional credit business dominated by commercial banks.

According to the National Bureau of Statistics in 2017, from January 2002 to December 2016, the proportion of new RMB loans in the scale of social financing decreased from $91.9 \%$ to $67.4 \%$. However, in the scale of social financing, non-banks financing instruments increased rapidly; the proportion rose from $8.1 \%$ to $32.6 \%$. In terms of social financing channels, the financing efficiency of non-bank institutions is high. Looking at the overall social financing level, the support of issuing RMB loans to real economy increased by $13.2 \%$ year-on-year; Trust loans increased by $15.8 \%$ year-on-year; Entrusted loans increased by $19.8 \%$ year-on-year; Corporate bonds increased by $22.5 \%$ year-on-year; Undiscounted bank acceptance bills decreased by $33.4 \%$ year-on-year; The domestic 
shares of non-financial enterprises increased by $27.6 \%$ year-on-year ${ }^{1}$, and the scale of social indirect financing is huge.

Commercial banks are emerging as a powerful force for change. The steady implementation of interest rate liberalization, the sudden emergence of Internet finance, and the concentrated release of financial risks have fully proved that financial disintermediation has stepped into a deeper level irreversibly. In the post-financial reform era under the financial disintermediation, how to achieve strategic transformation, seize reform opportunities, adjust business layout to seize opportunities, how to reform internal power, turn disadvantages into advantages, how commercial banks use their strong customer base to reform credit online business and maintaining core competitive advantages become a key issue that needs to be resolved in the current banking industry.

This article research on the impact of financial disintermediation on the credit business of Chinese commercial banks, the rest of the article is organized: The Chapter 2 is literature review about the research theme. The Chapter 3 mainly elaborates the current situation of China's financial disintermediation and the main reasons. The Chapter 4 explores the impact of financial disintermediation on Chinese commercial banks. Finally, based on the financial disintermediation circumstance, Chapter 5 proposes countermeasures for Chinese commercial banks in terms of optimizing business structure, accelerating strategic transformation and reforming traditional service models. The Chapter 6 is the main innovations and limitations.

\section{Literature Review}

\subsection{The Connotation of Financial Disintermediation}

The essence of financial disintermediation is the general trend of direct financing instead of indirect financing. The benefit of financial disintermediation lies in the fairness and openness of competition between the parties involved in fund borrowing and borrowing in the financial market. In addition, the financial environment tends to be stable under indirect currency control (Xin, 1990). The phenomenon that funds cross over financial intermediaries such as commercial banks and directly establishes a connection between financing demanders and suppliers is financial disintermediation, financial intermediary refers not only to commercial banks, but also to financial intermediaries in a broad sense. The process of China's financial disintermediation is manifested in the establishment of a multi-level, fully functional financial market (Tang, 2006). With the improvement of the direct financing market, the stock capital of commercial banks is attracted to the capital market, resulting in financial disintermediation (Li, 2007). Financial disintermediation means financial intermediaries lose their previous intermediary functions, and the actual performance is that financial intermediary activities span financial intermediaries. In China, there is more "disintermediation" of SMEs, with distinctive Chinese characteristics. Informal financial

${ }^{1}$ The data comes from AskCI website,

http://www.askci.com/news/finance/20170112/17534887639.shtml. 
institutions absorb a large amount of lost funds by commercial banks. Financial disintermediation is essentially an asset-liability relationship, that is, the transfer of capital from those with surplus funds to those with shortfalls (Feng, 2015).

In financial disintermediation, "intermediation" in the narrow sense refers specifically to commercial banks, and in a broad sense includes numerous financial institutions. Chinese commercial banks basically assume all the liquidity in the capital market, so financial disintermediation refers specifically to the disintermediation of commercial banks. In the field of financial disintermediation, Chinese scholars have conducted academic research closely in accordance with the actual situation in China in recent years. By using the MS-AR model to measure China's financial disintermediation indicators, the empirical conclusions show that China has significant financial disintermediation at both asset side and liability side, financial sector and banking sector. The disintermediation trend continues to strengthen and to be maintained for a long time in the long run (Song, 2011). In the post financial crisis era of gradual recovery, the original potential risks are exposed in multiple links of the background of financial disintermediation. To establish "the impact of financial disintermediation - the risk exposed in the dynamic impact - the control of financial disintermediation risk", which proves that the gradual evolution of financial disintermediation in China needs clear and prudent guidance and correct application (Shangguan \& Ren, 2012).

\subsection{The Impact of Financial Disintermediation on Chinese Commercial Banks}

Financial disintermediation has its own advantages and disadvantages, which are conducive to commercial bank business innovation and encourage sustainable development. Its disadvantage is that the deposit and loan business of commercial banks has been greatly impacted (Li, 2006). In the context of financial disintermediation, the deposit and loan spreads have tightened, the ratio of deposits and loans has gradually decreased, and the attractiveness of bank loans to corporate customers has declined. Chinese commercial banks should actively develop settlement systems and vigorously improve and promote agency business (Fan, 2007). Bank spreads are gradually reduced due to financial disintermediation and the proportion of deposits and loans in total assets has shrunk. The deepening of bond and stock markets has diverted the bank's deposit and loan business. Financial disintermediation leads to the loss of banks' high-quality customers and asset structure, and the total amount is also adjusted (Lu, Ren, \& Shi, 2008). Commercial banks' response strategies are based on national policies, financial market environment, technology applications and openness, etc. (Xi, 2010).

Starting from commercial banks, study how financial disintermediation occurs and develop in China, and how its negative influence factors exacerbate the business risks of commercial banks (Hu \& Liu, 2010), and put forward effective measures to deal with financial disintermediation based on the research conclu- 
sions that commercial banks should actively develop the management of bank managers and the state should improve laws and regulations to increase the transparency of the capital market (Li \& Wang, 2010). By focusing on the impact of financial disintermediation on county-level commercial banks, non-bank financial intermediaries are increasingly prosperous, and third-party payment institutions, such as Alipay, have replaced high-quality customers of commercial banks and part of the bank's business. The proportion of demand deposits has increased and the proportion of medium and long-term savings deposits has been declining year by year, which severely impacted the savings deposit structure of commercial banks (Ding \& Li, 2013).

\section{Analysis on Current Situation of China's Financial Disintermediation}

\subsection{Disintermediation of SME Loans Is Becoming More Obvious}

The SMEs have the most obvious feedback on financial disintermediation in China because SME loans have taken the lead in showing a strong disintermediation effect. The development of China's securities market was not complete around 1976. A large amount of bank funds flowed to large state-owned enterprises, and loans to small and medium-sized enterprises were seriously lagging behind. Moreover, most of them are central-owned enterprises and state-owned holding units, credit assets are heavily accumulated in them resulting in a certain degree of inefficiency. Under the financial market environment at that time, many SMEs could hardly obtain financing and borrowing from commercial banks (Guo, 2013; Han \& Zhao, 2020; Jiang, 2021). Therefore, SMEs had to try private loans or raise funds through high-risk areas such as non-financial markets.

\subsection{Parallel Lending Behavior, More Non-Commercial Bank Financial Intermediaries Arise}

Nowadays, Internet platforms are in an endless stream. Financial companies well-known to the public have grown stronger. Internet financial companies such as Alibaba Finance, Baidu Finance, and Tencent Finance have penetrated into every corner of residents' daily lives. The establishment of P2P lending financial service platforms, the rise of third-party payment companies, and the production of private equity fund products have effectively solved the predicament of fund lending. The development of Internet media, online platforms, mobile applications, and mass credit has directly narrowed the distance between fund providers and demanders. Microfinance has increasingly played its advantages in timeliness, various small and micro loans such as personal consumption loans and credit loans have prospered.

\subsection{The Growth Rate of Chinese Commercial Bank Deposit Ratio Is Declining}

China's capital market started late. Compared with European and American economies, residents' savings and consumption concepts are lagging, and the 
real economy is under-supported. The relatively backward economic level makes residents more willing to save, and commercial banks' savings deposits have long accounted for a relatively large proportion. After 1980, the central bank tried the social issuance of treasury bills, and the central government's guidance on economic accelerated. Only then did residents change their investment methods and began to participate in the financial market. Investment concepts gradually enriched and new investment tools were incorporated into the financial market. Shanghai and Shenzhen stock exchanges have been established, and stock investment is widely accepted by residential investors. So far, fund, wealth management, and trust investment products become more abundant, investment channels and financing methods reached another peak, and residential investors abandoned their original commercial bank deposits and other simple investment behaviors. As of the end of 2017, the growth rate of total liabilities of commercial banks was only $8.4 \%$, which was nearly half the growth rate of the same period in $2016^{2}$. The decline in deposit growth is particularly noticeable.

\subsection{The Proportion of Enterprises Seeking Financing from Commercial Banks Is Slowing Down}

Commercial banks have a long history in core monopoly position on the financing side of the financial market in China. However, with the increasing improvement of the capital market and the continuous development of the financial market, the existing commercial financing situation is changing. At present, it is difficult for enterprises to obtain financing from commercial banks, so as a financial intermediary, the bank's monopoly position is gradually diverted and replaced by the capital market in the financing system. In recent years, enterprises generally feel that credit capital from commercial banks is "expensive and difficult to finance". Banks are increasingly rigorous in risk management, and entry barriers and policy red lines have become insurmountable gaps for enterprises. At the same time, companies can successfully implement stock and bond financing, and the NEEQ market opened a convenient window for SME financing channels. In the bill market and discount market, various financing bonds undergone tremendous changes. The issuance of ultra-short-term financing bills, medium- and short-term financing bills, and non-public directional additional issuance of financing bills has completely changed, which obviously shakens the position of commercial banks in the financing system.

Since the beginning of 2000, data from the People's Bank of China shown that in the total social financing scale, more than $90 \%$ of the total direct RMB loans accounted for at the social level. However, around 2014, the total direct RMB loans accounted for $50 \%$ of the total social financing. In addition, the proportion of equity and bond financing has steadily expanded from $4 \%$ when it started in 2000 to $16 \%$ in 2014 . At the same time, the increase in types of entrusted loan models, bill discounting and re-discounting, and multiple foreign currency fi-

${ }^{2}$ The data comes from the China Banking Industry Development Report (2018). 
nancing models further exacerbated financial disintermediation on the asset side of commercial banks.

\section{Analysis of the Impact of Financial Disintermediation on Commercial Banks}

\subsection{Impact on the External Operating Environment of Commercial Banks}

For the development needs of enterprises, most funds raised were obtained from banks in the past. However, the leverage ratio of enterprises was maintained at a high trend, and to a large extent the financial risks of banks will increase. The domestic securities market is constantly developing and improving. Enterprises can obtain development funds in the securities market to alleviate the plight of lack of funds. By this way, funds away from bank loans become the main part of corporate development funds, which can also reduce the bank's financial risks and improve external operating conditions.

\subsection{Impact on the Development of Banks Intermediary Business}

Under the guidance of financial disintermediation, the direct financing market has plenty of room for development, and many financial derivative markets appear, such as swaps and futures. These newly emerging commercial bank asset portfolio models can meet the financing requirements of different types of companies and increase the attractiveness of intermediary businesses. At the same time, some value-added services have also gained new profit growth points, such as venture capital and consulting.

\subsection{Impact on the Deposit and Loan Business of Commercial Banks}

Financial disintermediation is a "double-edged sword". Financial disintermediation can bring opportunities for commercial banks and make commercial banks face huge challenges. The traditional deposit and loan business has been the most affected. The emergence of financial derivatives and the loss of some high-quality customers have hindered the development of credit business. At the same time, for the development of enterprises, bank loans are no longer the main financing channel. More extensive financing methods aroused the attention of enterprises, so that enterprises' demand for financing through bank channels is far reduced.

\subsection{Internet Finance Impacts the Banks Traditional Business Model}

Internet finance is gradually changing people's payment methods and financial management concepts. With the development of the Internet and e-commerce, merchants and consumers tend to adopt various cashless payment methods. This model rapidly enlivens the market as soon as it is launched. Traditional credit card and cash payments have been replaced by fast cashless payment methods, 
providing merchants and consumers with a variety of consumption methods. This series of new changes have a huge impact on the traditional business model of banks and promoted the transformation of the traditional business model of the bank.

\section{Suggestions}

\subsection{Optimize Business Structure and Expand Credit for SMEs}

Chinese commercial bank loans are directed towards leading industries, large state-owned enterprises, and large projects. To a certain extent, this amplifies the impact of financial disintermediation on the credit business of commercial banks. The development strategy of investing in large enterprises is no longer suitable for the current economy environment. There are many SEMs in China, with favorable policies and considerable market space. Actively exploring the market of small, medium, and micro enterprises and optimizing the direction and amount of capital investment are important exports for adjusting the business structure.

First, optimize the organizational structure and add franchise business departments of SMEs. The clear division of labor of specialized teams is conducive to business development and innovation, and it is convenient for SMEs to find matching service institutions. It is not only an important guarantee for the efficient and scientific operation of market business of SMEs, but also a key element to attract customers of them. Secondly, establish a scientific system and tap high-quality SME customers. Starting with the problem of information asymmetry, improve and optimize the credit evaluation and credit investigation system, fully combine high-tech means such as big data and the Internet, and accelerate the marketization of credit guarantee. Thirdly, adhere to comprehensive innovation, and subdivide and personalize products and services. Improve the comprehensive financial service capability, establish standardized, scientific, and simplified credit business processes suitable for small, medium-sized and micro enterprises according to the business nature, and provide them with diversified and personalized products and services. Finally, reform post-loan management and formulate appropriate risk management and control strategies. To attach importance to the SME market, increase the proportion of investment and at the same time increase the work of post-loan management for SMEs. Optimize the risk early warning system and risk management evaluation mechanism, and use outsourcing flexibly when necessary to minimize the relatively high credit risk of SMEs.

\subsection{Commercial Banks Accelerate the Strategic Pace of Transformation and Development}

In the context of financial disintermediation, China's commercial banks should give full play to the basic service function of the banking industry, establish a customer-centered high-quality service system, and deeply tap the potential advantages of banks in information technology, customer market channels, reputa- 
tion and so on. Increase cooperation with other non bank financial intermediaries, broaden the scope of business intersection with other financial institutions, and actively expand intermediary business and off balance sheet business to increase other business income.

Establish and improve the business model of providing customers with solutions for investment, management consulting, asset preservation and value-added, and further consolidate the diversified business strategic model of commercial banks. Commercial banks should expand their business areas according to their own development status and current market development hotspots. The most important thing is to further expand the business varieties of intermediary business, such as bank financial products, medium-term note business, credit asset financial products, precious metal investment, change the traditional image of commercial banks, stabilize the diversified business model of banks, and strengthen the irreplaceable nature of commercial banks under the trend of financial disintermediation.

Reduce transaction costs by promoting businesses such as asset securitization and the transfer of credit products. Deepen financial innovation mechanisms, such as adopting market-based bidding to create opportunities for customers to purchase wealth management products. By strengthening internal management, reduce operating expenses, especially those related to the development and marketing of financial wealth management products. In addition, by reducing the cost of customers' purchase and financial management burdens, they can enhance customer investment confidence and increase customer loyalty, thereby expanding market share and improving competitiveness.

Commercial banks shall actively develop online banking, direct banking, and mobile banking services. Effectively respond to the challenges posed by third-party payment and electronic finance. Through direct selling, internet, and mobile banking, it can reduce existing operating costs and reduce the workload of counter businesses and achieve intelligent and convenient professional operating goals. By improving service efficiency and optimizing service quality, establish brand awareness and image, attract more potential customers.

\subsection{Accelerate the Transformation of Traditional Service Models of Commercial Banks}

With the emergence of the "Internet + Industry" model, information technology plays a pivotal role in facilitating the development and transformation of the industry. The rise of big data, cloud computing, artificial intelligence and other information technologies provides favorable external conditions for the transformation of the traditional financial industry. Chinese commercial banks should seize the opportunity to establish an "Internet + financial industry" thinking to innovate the traditional service model and establish an online and offline entity plus network integrated service platform. Carry out big data analysis on massive business information, understand customer needs and customer value, and establish a complete service system to better meet customer needs, provide the best 
customer experience, and tap customer value.

At present, the biggest competitor faced by commercial banks is Internet finance. As a traditional financial intermediary, banks should change its management concept and promote the promotion of intermediary business, online and mobile banking business. Commercial banks lack the awareness of Internet plus when promoting their financial products. Therefore, commercial banks should actively change concepts, fully promote internet financial online services, and accelerate the transformation of traditional service mode of commercial banks. Financial disintermediation led to the loss of a large number of high-quality customer resources. For this, commercial banks appropriately adjusted marketing strategies and maintained customer relations by using CRM theory and big data analysis results. At the same time, improve the credit system of middle-end customers, comprehensively improve the service quality of low-end customers, strengthen the diversification of financial services, change the previous pure asset liability business model, and provide more accurate financial services.

\section{The Innovation and Limitation}

This article combining legal policy, market environment, supervision and technology and other factors, a detailed analysis of the changes in China's financial asset structure, more clearly clarified the connotation, causes and development trends of financial disintermediation. At the same time, it effectively combines the current era background of Internet finance and the financial environment of interest rate marketization, and more professionally demonstrates how Internet finance and interest rate marketization reform the development model of bank credit business, and effectively promote the deepening of reform and strategic transformation of Chinese commercial banks.

The research of this article has a certain theoretical value. At this stage, financial innovation becomes a research focus that cannot be ignored. By focusing on the phenomenon of China's financial disintermediation in the context of Internet finance and other financial tools, the paper elaborates on the mechanism, performance, reasons and countermeasures of financial disintermediation, which has reference value for the government's financial policy formulation and implementation, and further enriches the achievements of scientific research projects and application value.

At present, it is still at the stage of qualitative research. Next, the authors will select financial disintermediation indicators for quantitative research, and further demonstrate the impact and influence of financial disintermediation on the credit business of Chinese commercial banks through empirical research.

\section{Acknowledgements}

The authors thank for Datong City's National Green Finance Reform and Innovation Pilot Zone Project (No. SXSJ-F3180621) supported by Datong Development and Reform Commission; The Datong City's Soft Science Project (2021182) supported by Datong Science and Technology Bureau; The youth project of the 
2021 annual planning project of Shanxi Academy of Social Sciences (Development Research Centre of Shanxi Provincial People's Government, Project No. YWQN202110); The special research of Yungang Studies supported by Shanxi Datong University (No. 2020YGZX098).

\section{Conflicts of Interest}

The authors declare no conflicts of interest regarding the publication of this paper.

\section{References}

Ding, Z. B., \& Li, J. (2013). Thoughts on the Operating Structure of County Commercial Banks under the Trend of Financial Disintermediation. Financial Aspects, 4, 48-54.

Fan, Y. Q. (2007). The Performance of Financial Disintermediation in My Country and Its Impact on Commercial Banks. Times Finance, 8, 49-50.

Feng, K., Hong, T., \& He, L. (2015). Analysis of the Impact of China's Shadow Banking on the Stability of the Banking System. Corporate Finance Research, 3, 34-44.

Guo, N. (2013). Government? Market? Who Is More Effective-A Study on the Effectiveness of the Financing Mechanism for SMEs. Financial Research, 3, 194-206.

Han, F. Q., \& Zhao, W. (2020). The Financing Dilemma of Small and Medium-Sized Enterprises: An Explanation and Response Based on Risk Governance. Macroeconomic Research, 8, 15-23+50.

Hu, H. Y., \& Liu, B. (2010). Research on the Diversification of Commercial Bank Asset Allocation under the Background of Financial Disintermediation. Southern Finance, 6, $78-80+43$.

Jiang, Z. L. (2021). Monetary Policy Choices and Macroeconomic Stability to Solve the Financing Problems of SMEs. International Finance Research, 4, 23-32.

Li, H., \& Wang, B. B. (2010). Financial Disintermediation and Risk Management of Commercial Banks. Seeking, 10, 47-49.

Li, J. (2006). Opportunities and Challenges Faced by Commercial Banks under the Trend of Financial Disintermediation. China Finance, 14, 12-14.

Li, Y. (2007). Disintermediation: New Challenges Facing China's Financial Reform and Development. New Finance, 11, 15-16.

Lu, M. F., Ren, Y. J., \& Shi, Y. (2008). Analysis of the Impact of Financial Disintermediation on the Management of Commercial Banks. Shanghai Finance, 6, 93-95.

Shangguan, Y. Q., \& Ren, B. Y. (2012). Financial Disintermediation (pp. 77-167). China Financial and Economic Publishing House.

Song, W. (2011). Research on China's Financial Disintermediation (pp. 123-159). Renmin University Press.

Tang, X. (2006). Promoting Case Studies and Promoting the Development of Financial Theory. Financial Research, 1, 1-6.

Xi, B. (2010). Financial Disintermediation and Countermeasures of Commercial Banks. Zhejiang Finance, 5, 34-35.

Xin, Q. (1990). Introduction to Italian Financial Disintermediation. International Financial Research, 8, 45-46. 